\title{
ATTACHMENT TO CAREGIVERS AND TYPE 1 DIABETES IN CHILDREN NAVEZANOST NA STARŠE IN SLADKORNA BOLEZEN TIPA 1 PRI OTROCIH
}

\author{
Maja DROBNIČ RADOBULJAC1,*, Yael SHMUELI-GOETZ² \\ ${ }^{1}$ University Psihiatric Hospital Ljubljana, Center for Mental Health, Unit for Adolescent Psychiatry, \\ Zaloska 29, 1000 Ljubljana, Slovenia \\ ${ }^{2}$ Clinical, Educational \& Health Psychology, Division of Psychology \& Language Sciences, \\ University College London, Gower Street, London WC1E 6BT, United Kingdom
}

\section{ABSTRACT}

Keywords:

attachment, children, type 1 diabetes, etiology, stress reactivity

\section{IZVLEČEK}

Ključne besede: navezanost, otroci, starši, sladkorna bolezen tipa 1, etiologija, stresna reaktivnost
Attachment is a behavioral and physiological system, which enables individual's dynamic adaptation to its environment. Attachment develops in close interaction between an infant and his/her mother, plays an important role in the development of the infant's brain, and influences the quality of interpersonal relationships throughout life.

Security of attachment is believed to influence individual response to stress, exposing insecurely organized individuals to deregulated autonomic nervous system and exaggerated hypothalamic-pituitary-adrenal activity, which, in turn, produces increased and prolonged exposure to stress-hormones. Such stress responses may have considerable implications for the development of diverse health-risk conditions, such as insulin resistance and hyperlipidemia, shown by numerous studies.

Although the mechanisms are not yet fully understood, there is compelling evidence highlighting the role of psychological stress in the development of type 1 diabetes (T1D). One of the possible contributing factors for the development of T1D may be the influence of attachment security on individual stress reactivity. Thus, the suggestion is that insecurely attached individuals are more prone to experience increased and prolonged influence of stress hormones and other mechanisms causing pancreatic beta-cell destruction. The present paper opens with a short overview of the field of attachment in children, the principal attachment classifications and their historic development, describes the influence of attachment security on individual stress-reactivity and the role of the latter in the development of T1D. Following is a review of recent literature on the attachment in patients with T1D with a conclusion of a proposed role of attachment organization in the etiology of T1D.

Navezanost je vedenjski in fiziološki sistem, ki posamezniku omogoča dinamično prilagajanje na okolje. Navezanost se razvija pri sovplivu med dojenčkom in materjo, igra pomembno vlogo pri razvoju otrokovih možgan in vpliva na kvaliteto posameznikovih socialnih odnosov vse življenje.

Varnost ali oblika navezanosti vpliva na posameznikov odziv na stres (stresno reaktivnost). Tako pride pri negotovo navezanih posameznikih do slabše reguliranega avtonomnega živčnega sistema in pretirane reaktivnosti hipotalamo-hipofizno-suprarenalne osi, zaradi česar so ti v življenju pogosteje in dalj časa izpostavljeni delovanju stresnih hormonov. Tovrsten odziv na stres pa ima pomembno vlogo pri razvoju inzulinske rezistence, hiperlipidemije in drugih stanj, ki predstavljajo tveganje za zdravje.

Čeprav natančni mehanizmi še niso znani, je vedno več dokazov, da psihološki stres pomembno prispeva k razvoju sladkorne bolezni tipa 1 (SBT1). Eden od mehanizmov razvoja te bolezni bi lahko bil tudi vpliv oblike navezanosti na posameznikovo stresno reaktivnost. Tako so lahko negotovo navezani posamezniki pogosteje, dlje in $v$ večji meri izpostavljeni delovanju stresnih hormonov, ki skupaj z drugimi dejavniki povzročajo uničenje beta celic trebušne slinavke.

Ta prispevek prikaže najprej kratek pregled področja navezanosti pri otrocih, glavne oblike navezanosti in njihov zgodovinski razvoj, oriše vpliv oblike navezanosti na posameznikovo stresno reaktivnost in vpliv te reaktivnosti na razvoj SBT1. Zaključi se s predlogom o vlogi oblike navezanosti pri razvoju SBT1 pri otrocih. 


\section{INTRODUCTION}

John Bowlby conceptualized attachment as an evolutionary behavioral system of comparable importance to the systems guiding feeding and reproductive behaviors (1). Contemporary theories describe it as a behavioral and physiological system with a biological basis in the orbitofrontal system of the right hemisphere and its cortical and subcortical connections (2). The infant or child dynamically adapts to its environment to regulate safety and survival by ensuring proximity of the caregiver or attachment figure in times of distress, using attachment behaviors that increase in their complexity with age. These include constant knowledge of the attachment figure's (an older person, most commonly the mother) whereabouts, using sounds to make her return when gone too far or fleeing to her if the distress or perceived danger rises to a level that is too high to endure on his own. Infant's attachment behavioral system is adapted to a complementary behavioral system of the attachment figure, namely, the care-giving system. This results in a behavioral interplay between the infant and the caregiver, in which the infant leaves 'the secure base' provided by the caregiver to explore, and returns back to 'the safehaven' when in distress (tired, ill, hungry, alarmed or just too far) to be calmed down and ready to leave again. Over time, the repeated interactions between the caregiver and the infant are internalized by the infant and captured into implicit memory as 'internal working models' (2). These early models are thought to guide expectations and behaviors in a largely unconscious way, and are thought to remain relatively stable across the lifespan, provided the family environment and the wider ecology remain stable as well (3).

\section{PATTERNS OF ATTACHMENT}

According to Bowlby's and Piaget's theory, and in line with the current knowledge on brain development, the attachment to one principal (mostly the mother) and one or more secondary attachment figures is formed between the age of 7 months and 2 years, when the object's constancy (the knowledge that mother exists even when not present or within sight) has developed $(2,4,5)$. Attachment continues to develop throughout childhood, depending on the stability or changes in the family environment $(3,4$, 6). Bowlby's early observations of the striking behaviours of children subjected to separation from, and loss of, their attachment figures were further supported by Ainsworth's observational studies of individual differences in the quality of the interactions between infants and their mothers. What emerged was the critical importance of how sensitive and responsive mothers responded to their infants' attachment bids. These early observations paved the way for the development of a structured laboratory assessment, the Strange Situation Procedure, as a way of accessing children's internal working models of attachment relationships (6). These were thought to be reflected in their behavior in response to a series of separations from, and reunions with, their caregivers. Three organized attachment strategies were identified and, subsequently, Main and Solomon added a fourth attachment category, capturing attachment disorganization (7). These were:

1. Secure attachment: infant shows signs of missing mother during her absence, greets her actively, seeks comfort, settles and returns to play. The mother's behavior at home was tender, careful holding with contingent face-to-face pacing of interactions, and with sensitivity to the infant's signals in the first year of life.

2. Insecure resistant/ambivalent attachment: infant appears preoccupied with mother throughout procedure, is either markedly angry or markedly passive, alternately seeking and resisting the mother, fails to settle or return to play on reunion and continues to focus on the mother and cry. The mother's behavior was inept in holding, noncontingent in face-to-face interaction and unpredictable, but not rejecting.

3. Insecure avoidant: infant focuses on the toys, does not cry during separation, actively avoids and ignores mother on reunion, moves away, turns away, leans away when picked up. The mothers of these infants rejected attachment behavior and were particularly averse to tactual contact.

4. Insecure disorganized/disoriented: infant displays disorganized or disoriented behaviors in the parent's presence (freezing all movements, rocking on hands and feet, hands in air, rise and then fall prone at parent's entrance). Mostly infants whose parents behaved towards them in abusive manner (7).

Attachment to caregivers develops disregarding the way the child is treated by them, even when the child is maltreated (8). Attachment behavior, although in a different form, becomes activated in adults as well, in the way of monitoring the availability of attachment figures (most commonly romantic partners, parents or close friends) and seeking them as 'stronger and wiser' in times of stress (9). The patterns of attachment are manifested in different ways across the life span, using different, but related, methodologies. The focus shifted from the study of individual differences in behavior to the study of internal working models as reflected in narratives (8).

\section{ATTACHMENT SECURITY AND STRESS REACTIVITY}

Research findings drawn from diverse perspectives converge in showing that an individual's behavioral and 
physiological response to a specific stressor is consistent throughout time and comparable in different species (10). The responses depend on the perception of the stressor as well as on the individual's stress reactivity and coping. Individual differences in stress response can be observed in different domains, namely: physiology, cognitive function, subjective experience and behavior (10). Within the physiological domain, changes responding to stressful experience can be divided into cardiovascular responses (indicated by blood pressure and heart rate), driven by autonomic nervous system activity, and metabolic responses produced by the output of the glucocorticoid hormone cortisol from the adrenal cortex, driven by hypothalamic-pituitary-adrenal (HPA) axis activity (10). Although physiological responses serve to meet metabolic demands posed by the stressor, prolonged exposure to the HPA axis hyperactivity may lead to insulin resistance, hyperlipidemia and other conditions with increased risk for health disturbance (11). Cognitive responses to stress include systems important in learning, memory as well as attentional processes (12). Within the subjective domain, the perception of the stressor in humans is believed to be determined within the orbitofrontal system of the right hemisphere (2), the most common emotional experience being fear and apprehension (13). Experiences that pose a risk are thought to activate the individual's attachment system and various physiological and behavioral mechanisms that are all directed towards homeostatically regulating the stress response, resulting in the deactivation of the attachment system (14). For example, the presence of a large dog will induce the feeling of fear in a small child and result in the child fleeing towards his/ her mother, aiming to be lifted up away from the danger, held and comforted until the danger subsides. When this occurs and the child finds a secure base in the attachment figure, his/her physiological functions (increased heart rate, shiver) and the feeling of fear return to normal, and the child is able to continue with play.

Secure attachment is believed to provide resilience in the face of stress, "which is expressed in the capacity to flexibly regulate emotional states via autoregulation and interactive regulation' (2), using internalized coping mechanisms and interaction with the attachment figure (2). Studies investigating stress reactivity in humans and animals have shown secure attachment to result in adaptive hypoactivity of the HPA axis, resulting in lower levels of stress hormones' release under the influence of psychological stress (15). Conversely, unresponsive or neglectful parenting and child maltreatment have been associated with blunted early morning cortisol levels, no diurnal decrease in cortisol and an exaggerated cortisol response to stressful situations, although the mechanisms behind are complex (16).
Various studies have shown that securely attached children, under stressful circumstances, maintain low levels of cortisol when in the presence of attachment figure, while insecurely attached (especially disorganized) children's cortisol responses were high (17-20).

\section{THE ROLE OF STRESS IN THE DEVELOPMENT OF TYPE 1 DIABETES}

The etiology of type 1 diabetes (T1D) has been extensively studied, with some clear findnings (21-24), but many questions have yet to be addressed (25). The mechanisms implied in the etiology of T1D are viral infection, seasonality, rapid growth, psychological stress, and many others, yielding conclusions of multi-factor origins of the disorder (21-24).

One of the proposed hypotheses on etiology of T1D assumed the destruction of pancreatic beta-cells was a result of functional overload of the cells, caused by overfeeding, accelerated growth at puberty, low physical activity as well as psychological stress (with elevations in cortisol, other stress hormones and autonomic nervous system imbalance), which all resulted in elevated needs for insulin production (24).

There is evidence for the role of diabetes-related autoimmunity in the destruction of pancreatic betacells and development of T1D. However, not all subjects with diabetes-specific autoantibodies develop clinical syndrome, and not all patients with T1D produce such antibodies. Sepa et al. conducted a wide prospective population-based study on more than 5000 newborns, with a follow-up of 1845 subjects after 2,5 years. Their results showed associations of serious life-events (such as divorce or death in the family) with diabetes-specific autoantibody status of babies without clinical diabetes. The association remained in the follow up sample, where $12,5 \%$ of children exposed to divorce developed autoimmunity, as compared to $3,8 \%$ of the children without the experience of divorce (26).

Veronique Mead elaborated on a hypothesis, which included the role of stressful life-events in the critical period of brain development, namely, experiencedependent maturation. She argues that 'disruptions in early bonding and attachment, including adverse events, such as traumatic stress, are capable of causing: (1) longterm imbalances in autonomic regulatory function and (2) relative dominance of sympathetic or parasympathetic activity.' The proposed mechanisms would again program an individual's autonomic nervous system and HPA axis, and expose the individual to higher insulin demands, as well as influence the immune system (27). 
Taking all these into account, Ludvigsson proposed a unifying theory wherein various genetic, environmental and co-regulating factors were included as explanatory factors. In the proposed 'beta-cell stress hypothesis,' functional overload of the beta-cells as a result of multiple factors resulted in overexpression of specific antigens on the cells which mediated their destruction (28).

\section{ATTACHMENT SECURITY AND DIABETES}

There is only a scarcity of data on the attachment to caregivers or adults in close relationships in patients with diabetes. Ciechanowski et al. found dismissing attachment in the setting of poor patient-provider relationship to be associated with poorer treatment adherence in patients with type 1 and 2 diabetes. The study was performed using self-report measures of attachment security with 367 subjects (29). The same group then performed a cross-sectional study using self-report measures with 4095 adult primary care patients with diabetes type 1 or 2 . Their results confirmed previous findings by showing that patients with dismissing attachment cooperated less well in their treatment than secure or preoccupied patients (lower levels of exercise, food care, diet and adherence to medications and higher rates of smoking), however, the patients with preoccupied attachment style were least likely to have worse metabolic control (not the securely attached). They concluded that insecure dismissing attachment is associated with worse diabetes outcomes, while secure and insecure preoccupied attachment predisposes to better outcomes (30).

Colton et al. studied disturbed eating behaviors in 106 girls with T1D in a one-year follow-up study using Children's Eating Disorder Examination Interview. They concluded that a more disturbed attachment to mother was one of the predictors of a new onset of eating disturbances (31). Rosenberg et al. performed a pilot study using self-report questionnaires on 31 families of adolescents with T1D, hypothesizing that attachment security to parents would be associated with metabolic control in adolescents. They were able to show only that maternal perceptions of more secure adolescents' attachment, not adolescents' reports, were associated with better glycemic control, although they concluded that the mechanism of the association was unclear (32).

Sepa et al. proposed that psychological stress could, via hormonal mechanisms, increase insulin resistance and trigger diabetes-related autoimmunity (33). They hypothesized that infants with diabetes-specific autoantibodies were more likely to have insecurely attached mothers than their antibody-negative peers. They interviewed 18 mothers of infants who were antibody-positive and 32 mothers of antibody-negative infants, using the Adult Attachment Interview (34).
Although failing to reach statistical significance, the proportion of children with insecurely attached mothers was substantially larger in the antibody-positive group (33\% compared to $19 \%$ and $33 \%$ compared to $20 \%$ for two types of diabetes-specific autoantibodies) (33).

\section{CONCLUSIONS}

Although not yet fully understood, growing evidence points to the role of psychological stress in the development of T1D. One of the possible mechanisms could be mediated through the child's attachment security and the influence of the attachment organization on stress reactivity, namely, the autonomous nervous system and the HPA axis reactivity. It is argued that insecurely attached, especially disorganized, children would be subjected to higher levels of stress hormones during exposure to stressful life-events. Insecure attachment and increased physiological stress reactivity would represent one of the factors contributing to the beta-cell overload, and, through the process of autoimmunity, peripheral tissue insulin resistance or some other as yet unknown process result in the destruction of beta-cells and clinical diabetes.

\section{CONFLICTS OF INTEREST}

The authors declare that no conflicts of interest exist.

\section{FUNDING}

None.

\section{ETHICAL APPROVAL}

Not required.

\section{REFERENCES}

1. Bowlby J. Attachment and loss. Vol. 1: Attachment. London: PIMLICO, 1969.

2. Schore AN. Attachment and the regulation of the right brain. Attach Hum Dev 2000; 2: 23-47.

3. Waters E, Merrick S, Treboux D, Crowell J, Albersheim L. Attachment security in infancy and early adulthood: a twenty-year longitudinal study. Child Dev 2000; 71: 684-9.

4. Bowlby J. A secure base. London, New York: Routledge Classics, 2010.

5. Piaget J, Inhelder B. The psychology of the child. New York: Perseus Books Group, 1972.

6. Ainsworth MD. Patterns of infant-mother attachments: antecedents and effects on development. Bull N Y Acad Med 1985; 61: 771-91.

7. Main M, Solomon J. Procedures for identifying infants as disorganized/ disoriented during the Ainsworth strange situation. In: Greenberg MT, Cichetti D, Cummings EM, editors. Attachment in the preschool years: theory, research and intervention. Chicago: University Press, 1990: $121-60$. 
8. Main M. Introduction to the special section on attachment and psychopathology: overview of the field of attachment. J Consult Clin Psychol 1996; 64: 237-43.

9. Bowlby J. Attachment and loss. Vol. 3: Loss - sadness and depression. London: PIMLICO, 1998.

10. Koolhaas JM, de Boer SF, Coppens CM, Buwalda B. Neuroendocrinology of coping styles: towards understanding the biology of individual variation. Front Neuroendocrinol; 31: 307-21.

11. Rosmond R, Bjorntorp P. The hypothalamic-pituitary-adrenal axis activity as a predictor of cardiovascular disease, type 2 diabetes and stroke. J Intern Med 2000; 247: 188-97.

12. Arnsten AF. Catecholamine modulation of prefrontal cortical cognitive function. Trends Cogn Sci 1998; 2: 436-47.

13. Meaney MJ. Maternal care, gene expression, and the transmission of individual differences in stress reactivity across generations. Annu Rev Neurosci 2001; 24: 1161-92.

14. Nolte T, Guiney J, Fonagy P, Mayes LC, Luyten P. Interpersonal stress regulation and the development of anxiety disorders: an attachmentbased developmental framework. Front Behav Neurosci 2011; 5: 55.

15. Gunnar M, Quevedo K. The neurobiology of stress and development. Annu Rev Psychol 2007; 58: 145-73.

16. Tarullo AR, Gunnar MR. Child maltreatment and the developing HPA axis. Horm Behav 2006; 50: 632-9.

17. Gunnar MR, Donzella B. Social regulation of the cortisol levels in early human development. Psychoneuroendocrinology 2002; 27: 199220.

18. Kertes DA, Donzella B, Talge NM, Garvin MC, Van Ryzin MJ, Gunnar MR. Inhibited temperament and parent emotional availability differentially predict young children's cortisol responses to novel social and nonsocial events. Dev Psychobiol 2009; 51: 521-32.

19. Spangler G, Grossmann KE. Biobehavioral organization in securely and insecurely attached infants. Child Dev 1993; 64: 1439-50.

20. Hertsgaard L, Gunnar M, Erickson MF, Nachmias M. Adrenocortical responses to the strange situation in infants with disorganized/ disoriented attachment relationships. Child Dev 1995; 66: 1100-6.

21. Oldstone $M B$, Nerenberg $M$, Southern P, Price J, Lewicki $H$. Virus infection triggers insulin-dependent diabetes mellitus in a transgenic model: role of anti-self (virus) immune response. Cell 1991; 65: 31931.
22. Rothwell PM, Gutnikov SA, McKinney PA, Schober E, lonescuTirgoviste C, Neu A. Seasonality of birth in children with diabetes in Europe: multicentre cohort study. European Diabetes Study Group. BMJ 1999; 319: 887-8.

23. Toniolo A, Onodera T, Yoon JW, Notkins AL. Induction of diabetes by cumulative environmental insults from viruses and chemicals. Nature 1980; 288: 383-5.

24. Dahlquist G. Can we slow the rising incidence of childhood-onset autoimmune diabetes? The overload hypothesis. Diabetologia 2006; 49: 20-4.

25. Ludvigsson J. Is it time to challenge the established theories surrounding type 1 diabetes? Acta Paediatr 2014; 103: 120-3.

26. Sepa A, Frodi A, Ludvigsson J. Mothers' experiences of serious life events increase the risk of diabetes-related autoimmunity in their children. Diabetes Care 2005; 28: 2394-9.

27. Mead VP. A new model for understanding the role of environmental factors in the origins of chronic illness: a case study of type 1 diabetes mellitus. Med Hypotheses 2004; 63: 1035-46.

28. Ludvigsson J. Why diabetes incidence increases-a unifying theory. Ann N Y Acad Sci 2006; 1079: 374-82.

29. Ciechanowski PS, Katon WJ, Russo JE, Walker EA. The patientprovider relationship: attachment theory and adherence to treatment in diabetes. Am J Psychiatry 2001; 158: 29-35.

30. Ciechanowski P, Russo J, Katon W, Von Korff M, Ludman E, Lin E. et al. Influence of patient attachment style on self-care and outcomes in diabetes. Psychosom Med 2004; 66: 720-8.

31. Colton PA, Olmsted MP, Daneman D, Rydall AC, Rodin GM. Natural history and predictors of disturbed eating behaviour in girls with Type 1 diabetes. Diabet Med 2007; 24: 424-9.

32. Rosenberg T, Shields CG. The role of parent-adolescent attachment in the glycemic control of adolescents with Type 1 diabetes: a pilot study. Fam Syst Health 2009; 27: 237-48.

33. Sepa A, Frodi A, Ludvigsson J. Mothers' attachment insecurity and diabetes-related autoantibodies in their infants. Ann N Y Acad Sci 2004; 1037: 110-3.

34. van IJzendoorn $\mathrm{MH}$. Adult attachment representations, parental responsiveness, and infant attachment: a meta-analysis on the predictive validity of the Adult Attachment Interview. Psychol Bull 1995; 117: 387-403. 